Research Article

\title{
Remnants of the Waikato: Native forest survival in a production landscape
}

\author{
Mairi Jay \\ Department of Geography, Tourism and Environmental Planning, University of \\ Waikato, Private Bag 3105, Hamilton, New Zealand
}

\begin{abstract}
This paper addresses the issue of conservation of native biodiversity on privately owned farmland in New Zealand. Based on surveys of Waikato dairy farmers as exemplars of intensive agricultural practice, it examines factors that influence the survival of native forest on land with potential for commercial production. Results suggest that a significant proportion of Waikato dairy farmers regard native forest favourably, although the proportion of farmers who actively conserve their forest is small. Factors that assist the persistence of native forest on dairy farms include personal characteristics of the farmer, past accidents of history which have left forest remnants in place, and physical characteristics of the farm such as topography. While the conservation of native biodiversity within this intensively farmed landscape is strongly influenced by political economy pressures that encourage production, non-utilitarian motives such as aesthetic enjoyment and family heritage can serve to counter the production ethic.
\end{abstract}

Key words: biodiversity conservation, farming, New Zealand.

Loss of biological diversity has become an issue of world-wide concern as natural wetlands and forests shrink in the face of economic and human population growth and accompanying development (Ehrlich \& Ehrlich 1981; Mooney et al. 1995). Concern for native biodiversity has been echoed in New Zealand (Atkinson \& Cameron 1993; Pryde \& Cocklin 1998). New Zealand's 1997 State of the Environment report notes that, 'Biodiversity decline is New Zealand's most pervasive environmental issue, with $85 \%$ of lowland forests and wetlands now gone, and at least 800 species and 200 subspecies of animals, fungi and plants considered threatened' (Ministry for the Environment 1997: 10-16). Concern for biodiversity prompted the government to publish a national strategy for conservation of indigenous biodiversity and the genetic diversity of introduced species (Department of Conservation and Ministry for the Environment 2000: 15-21).

An element of the concern, world-wide and in New Zealand, is for biodiversity loss caused by modern agriculture (Council of Europe 2002; Ministry for the Environment 2000a; 2000b; Benton et al. 2003; Parliamentary Commissioner for the Environment 2001; UK Government 1994; Vandermeer et al. 1998). Conservationists increasingly recognize that protection of a representative range of indigenous biodiversity must occur within cultivated and pastoral landscapes rather than areas set aside for such purposes (Western 1989; Lambeck et al. 2000; Mitchell \& Craig 2000: 158-165).

Note about the author: Mairi Jay is a senior lecturer in environmental planning. She has practiced as a conservation planner with the New Zealand Department of Conservation. Her main research interests relate to the social aspects of biodiversity conservation.

E-mail: mairij@waikato.ac.nz 
Habitat conservation on private land must be viewed against the spatial ecology of native biodiversity. The areas in New Zealand of highest biodiversity before European contact were the flood plains and coastal lowlands of the North and South Islands. Not only did they include the greatest diversity of ecosystems (coastal and low altitude forest of various structure and species composition including bog, swamp, flood plain, estuaries, dunelands, lakes, rivers, and streams), but they were also critical for the year-round ecology of many birds. Norton and Miller (2000: 27) cite the estimate of botanist P. de Lange that $20 \%$ of threatened vascular plants are confined to private land while a further $60 \%$ have their largest populations on private land. Holland (1997: 6) has argued that if we are to occupy islands sustainably we must learn to maintain their distinctive species by 'facilitating sustainable mixtures of native and exotic species in permanently settled areas'.

Given the importance of native habitat on private land for retaining a full range of pre-European biodiversity, the decisions that farmers make about native habitat on their land is significant. An aim of the research underlying this paper was to answer the two questions: Why is there so little native forest left in the Waikato? Why is there still some native forest left standing?

The research sought to identify factors that influence farmers in the way they perceive and manage their farms, and test whether farmers with bush on their land are different from those without bush. Farmers within the Waikato and Hauraki Plains were the focus of the research because they include some of the most productive farmers in New Zealand and because they are part of a global system of industrial agriculture.

Bowler (1992: 11-13) has summarized the characteristics of industrial agriculture in westernised countries as a process by which farming becomes increasingly subject to industrial modes of food production. It involves the creation of economies of scale, increased reliance on purchased inputs from other sectors of the economy (e.g. machinery, fertilizers, feed, agri-chemicals), resource substitution (capital for land and labour), the implementation of organizational features associated with the business firm, specialization of the labour function, and mechanization of the production. Food production becomes subordinate to food processing and manufacture. Many of the processes that characterize industrial agriculture involve management practices that cumulatively undermine local social and biophysical diversity, and in doing so, undermine the survival of indigenous habitat and species (Potter 1998; Wilson 2001; Council of Europe 2002).

Waikato dairy farming and the organization of the New Zealand dairy industry reflect most of the characteristics described by Bowler. Farms and farm management are closely integrated with the industrial processing of milk into milk products and depend on a highly specialized scientific infrastructure of pasture, livestock breeding and welfare, as well as capital intensive technology for milking and milk quality control.

Fonterra Co-operative Group (Fonterra 2004), with more than 13000 of the nation's 13800 dairy farmers, collects over 13 billion litres of milk per year and processes it into more than 600 products (e.g. fresh and frozen desserts, milk powders and proteins, cheeses and cheese ingredients, and pharmaceuticals). Approximately $96 \%$ of domestic milk production is exported. Bulk commodity milk powder and specialized milk products are exported to 140 countries. Because of trade barriers to the wealthy markets of Europe and North America, it is the middle income countries of Asia and Central and South America which provide the main market for New Zealand's commodity production, and the largest source of revenue. Because of this dependence on middle income countries as the main source of revenue Fonterra aims to be 'the lowest cost supplier of commodity dairy products' (Fonterra 2004). This means that New Zealand farmers face strong pressure to keep their production costs low. There is little incentive to invest in environmental amenity or protection unless there is economic justification.

The productivist practices typical of New Zealand dairy farming and other capital intensive forms of modern Western agriculture have 
been widely explored in the social sciences, particularly from a political economy perspective that has linked changes in agricultural practice with changes in economic power (Friedland et al. 1991; Bowler 1992; Bonanno et al. 1994; McMichael 1994; Potter 1998). The power of producers (farmers) has receded with the rise, first, of food processing and manufacturing organizations, and second with the increasing importance of the giant retail chains such as Sainsbury, Tesco and Wal Mart (Burch \& Goss 1999; Pritchard 1998).

In terms of the current survey, it can be inferred that the relationship of dairy farmers to the Waikato landscape will be fundamentally shaped by their position within an industrial food processing organization that aims to maintain its advantage in a competitive global marketplace through a strategy of low-cost production. New Zealand dairy farmers receive little or no support for environmental initiatives and are dependent on milk payments for most of their income. ${ }^{1}$ From a political economy perspective, we might predict that Waikato dairy farmers will face pressure to maximize production on land suitable for production and minimize expenditure on environmental stewardship.

The Waikato lowlands and Hauraki Plains are representative of the process of native habitat loss in the face of intensive agricultural development. The region supports $32 \%$ of the national dairy herd (Ministry of Agriculture and Forestry 2004a,b) and includes areas with the highest density of dairy cows in the country (Waipa and Matamata-Piako districts) (Livestock Improvement Corporation 2003). Non-point source pollution from agriculture has caused significant degradation of developed catchments in the region (Environment Waikato 1998: 135-150). Since the beginning of European settlement, native vegetation has been reduced to $18 \%$ in the lowlands, with only $6 \%$ of the former lowland and coastal forest still remaining (Leathwick et al. 1995). Wetlands have been reduced to approximately $25 \%$ of their former extent (Environment Waikato 1998: 181). ${ }^{2}$ In the Hamilton and Waipa Ecological Districts less than $1 \%$ of former wetlands now remain (Leathwick et al.1995: 2). The health of remaining wetlands and forest in the region, as well as their populations of native birds, fish, insects and plants, are threatened by continued agricultural development, particularly dairying (Champion 1988; Environment Waikato 1998; Boothroyd et al. 2000; Burns et al. 2000).

\section{Attitudes, values and concerns of New Zealand farmers}

There is a growing body of research on the environmental attitudes, values and practices of New Zealand farmers and other landowners (Bradshaw et al. 1998; Wilson 1992; Cocklin \& Dorman 1994; Fairweather \& Keating 1994; Jones et al. 1995; Parminter \& Perkins 1997; Menzies 1999; Davis \& Cocklin 2000; Rhodes et al. 2000; Underwood \& Ripley 2000). Wilson (1992) concluded that utilitarian attitudes toward native bush prevail among farmers of the Catlins district of the South Island and that, on the majority of farms in this district, native forest persists only because those areas are perceived as unsuitable for farming (Wilson 1992: 124). Attitudes toward native forest may vary regionally, however. A survey of 80 landowners in Rodney District, north of Auckland, by Cocklin and Dorman (1994) discovered that owners valued their bush for scenic/aesthetic reasons, wildlife, and heritage value.

For the nation as a whole, the Queen Elizabeth II National Trust (QEII 2002) reported in August 2002 that it had 1620 registered covenants protecting 56000 ha and that, 'our work represents only a tiny fraction of the need and the opportunity for conservation on private land, the limiting factor being funding [to cover the legal costs of covenanting]'. This fact suggests that, New Zealand-wide, a significant number of rural landowners are prepared to go to some length to protect areas of native vegetation.

In relation to environmental issues more broadly, Menzies (1999) found that South Island dairy farmers regarded environmental care as an important element of being 'clean and green', but more often as an ideal rather than a practise. A study of the values and goals of 1137 central North Island farmers by Parminter and Perkins (1997: 108) found that 
production goals outweighed environmental goals for most farmers, although most farmers ranked environmental goals relatively highly.

In a study of sheep and beef farmers in Northland, Bradshaw et al. (1998) found that despite costs of on-farm environmental stewardship approximately one-third of their respondents undertook tree planting, fencing of watercourses to exclude stock, and fencing of native bush. Motivations for such activities included utilitarian reasons (e.g. a desire to prevent stock losses in water courses), but also aesthetic and heritage reasons. Similarly, Rhodes et al. (2000) found substantial commitment to sustainable land management by North Island hill country farmers including planting shelter belts, erosion control measures, establishment of conservation reserves, and a concern for the aesthetic quality of the land. They concluded that 'farmers' commitment to sustainability and environmental management is explained in terms of an array of personal and community values which frequently over-ride financial conditions' (Rhodes et al. 2000: 2).

Underwood and Ripley (2000) argue that the generation of adequate income/profit is the most important single issue for farmers, and influences their economic and environmental performance. This view is supported by Rauniyar and Parker (1998), who noted that no matter how sympathetic to environmental issues farmers may be, they are unable to commit resources if financial and other pressures (such as availability of labour) make such effort impossible. Key constraints to the adoption of sustainable farming practices included low income, high debt, an ownership structure which limited the farmer's freedom to make management decisions, availability of labour, and how long the farmer expected to remain on the farm. In addition, socio-economic and personal factors affected the likelihood of farmers adopting environmental and sustainability practices, including age, education, and household structure.

The foregoing studies suggest that environmental stewardship on private land, including protection of native bush, is not a straightforward economic or utilitarian issue. The studies suggest that attitudes towards native vegetation may vary from one part of the country to another and in accord with farm management goals and objectives. For a majority of the farmers who undertake environmental protection, utilitarian motives seem to be the most important, but non-utilitarian attitudes may also be significant. Non-utilitarian motives may be influenced by personal factors such as age, education, stage of the family cycle, or the length of time a farm has been in the family, and expectations of succession.

\section{Research methodology}

The qualitative research component of this study included participant observation of five 'typical' dairy farm families over a 9-month period, and in-depth interviews of 10 'conservation' farmers who had set land aside under a conservation covenant. The quantitative research involved a telephone questionnaire survey of 130 dairy farmers selected at random from electoral lists for the Waikato, northern King Country and Hauraki Plains. The typical' families were average in terms of size of herd and size of farm for the Waikato and Hauraki Plains, but above average in terms of milk production statistics. ${ }^{3}$ The second sample of 'conservation' farmers were little different from the 'typical' farmers in terms of herd size and farm size, but were closer to the average (i.e. they were slightly lower) in terms of their milk production.

Comparative analysis from the qualitative research showed fundamental similarities between the management practices and farming philosophy of conservation farmers and typical farmers. Superficially, there was little to distinguish between them, apart from the obvious fact that the latter had set aside land from production and that they farm less intensively. None of the conservation farmers saw themselves as significantly different from other farmers, and all identified as farmers first and foremost. All derived their main income from dairy farming and were subject to the same industry requirements (in relation to milk hygiene, animal health and welfare, milk payment 
systems). Nevertheless, it was possible to detect differences in the weighting of management priorities and in their relationship to the land. As a group, conservation farmers appeared to be less driven by a production ethic, to be more individualistic in their farming style and farming philosophy, to know their farms better, to view their farm in a more personal way, to be more conservative or risk-averse in their farm management, and to look to spouses or close family for support rather than farming peers. These differences are subtle and are not necessarily specific to conservation farmers; they may be qualities that apply to greater or lesser degree to a broad spectrum of farmers including farmers who are 'typical' in other respects.

To extend the insights from the qualitative research a questionnaire survey of 130 dairy farmers in central Waikato and the Hauraki Plains was completed. The majority of farmers are likely to fall between conservation farmers at one end of the continuum and farmers with little or no concern for native habitat at the other. A survey can indicate what proportion of dairy farms retained any native vegetation (as perceived by the farmer) as well as the range of attitudes and values that farmers place on bush remnants. ${ }^{4}$

For the questionnaire survey, farmers were asked whether or not they had bush on their farm and questions about their farm management practices and priorities. Comparison with Livestock Improvement Corporation's Dairy Statistics (Livestock Improvement Corporation 2000) indicated that the sample was weighted toward farmers with above average milk production. As will become clear, 'farmers with bush' are not the same as 'conservation' farmers. Whereas the conservation farmers were selected on the basis that they had shown active concern for bush by covenanting it, 'farmers with bush' included farmers who retain native bush but do nothing to protect it.

\section{Survey results}

Forty-three percent of farmers (56 of 129) reported that they had some form of native

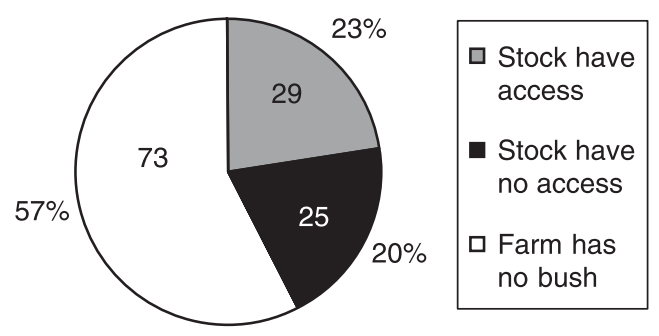

Figure 1 Number and proportion of farmers who reported they had bush to which stock had access, bush with no stock access, and no bush.

vegetation on their farm. Because access by farm livestock affects the health and long-term viability of forest remnants, farmers were asked about stock access to their bush. ${ }^{5}$ Of those with bush, $54 \%$ ( 29 of 54 of those responding to the question) reported that stock had access to the bush. Figure 1 shows the proportion of farmers who had no bush on their property, those who had bush but with stock access, and those who had bush protected from stock access.

The survey results confirmed that for the majority of farmers there is little to distinguish between those with bush and those without. Dairy farmers with and without bush on their farms were compared by age of respondent, farm ownership status, values and management priorities. For almost all characteristics, chi square tests of significance revealed virtually no differences between the two groups. Only age and ownership status suggested there could be some difference between those who had bush and those who did not.

Figure 2 shows the relationship between age of the farmer and presence of native bush. It suggests there is a positive relationship between age and bush on the farm up to a certain age, and a negative relationship thereafter. As farmers get older, up to the 45-54-year-old age category, they are more and more likely to report bush on their farm, but there is an abrupt drop among farmers in the 55-64-yearold age group who are least likely to report bush (apart from two in the 60-plus age group).

The data suggest that, aside from the two farmers over 65 , older farmers may be opposed to native bush on the farm while younger 


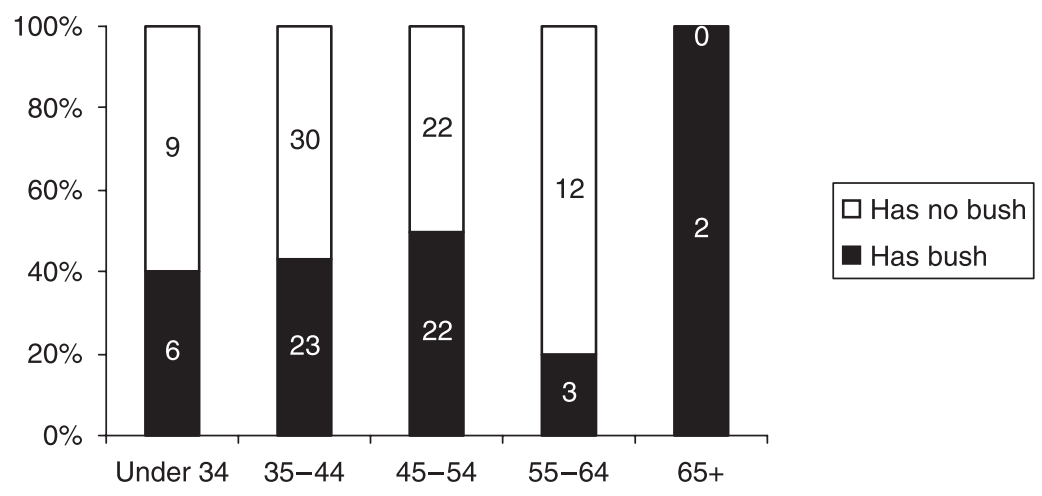

Figure 2 Forest remnants by age groups of farmers.

farmers are either in favour or do not mind one way or the other. The data support anecdotal evidence that many older farmers associate bush with poor farming practices (untidiness, laziness and wastefulness) while younger farmers are more inclined to view native bush favourably because they associate it with a distinctive New Zealand identity. Anecdotal evidence also suggests that middle-aged farmers (aged 45-54 years) are more likely than young farmers to have proved themselves competent as farmers and repaid their loans on purchasing the farm, thus facing fewer pressures to maximize production and pay off their loans. All of the conservation farmers involved in the qualitative survey were in the 45-54-year-old age category or had inherited their farm from their father, and it is likely that they experienced lower financial pressures than younger farmers.

Ownership status can influence the balance of priorities between generating income and caring for the land. In general, owners have a greater commitment to the long-term health of the land than sharemilkers or employees, who depend on production for their income. Figure 3 relates ownership status to the presence or absence of bush. If we exclude the category of 'herd manager/other' which only has four members (and is susceptible to chance error), farmers who both own and manage their farm are most likely to have bush (48\%). Farms that are managed by sharemilkers are less likely to have bush, and farms that are

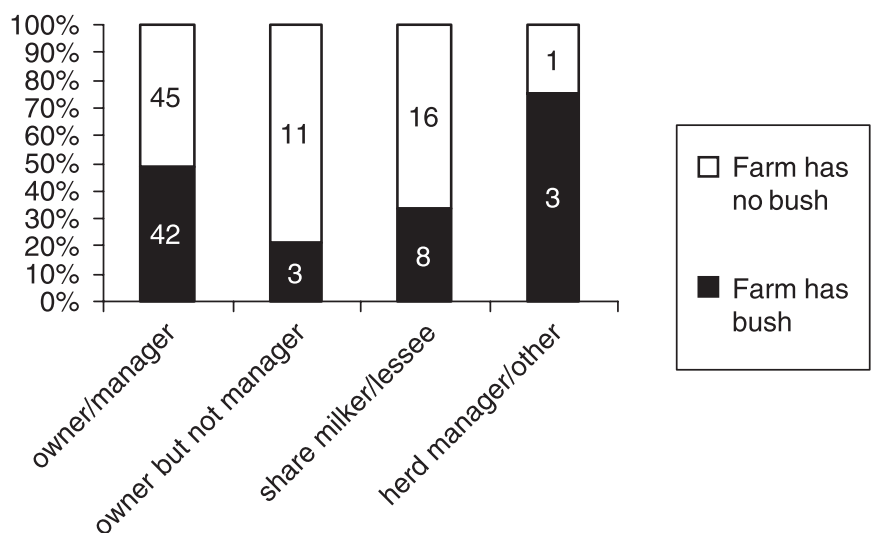

Figure 3 Percent of farms with or without forest remnants by the type of ownership or management of the farm. 
owned but not managed by the owner are least likely to have bush.

In summary, the questionnaire survey was unable to identify major differences in social and personal characteristics between farmers with bush and those without. This failure was likely due to the subtlety and complexity of personal and social variables that influence the way farmers manage their land, as well as the fact that 'farmers with bush' is a category that includes individuals with a wide range of attitudes to production on the one hand and conservation of native habitat on the other.

While the survey could not unscramble the complexity of the social and personal variables that influence the way farmers manage their land and native bush, it was able to explore variables related to the physical aspects which could affect bush survival. To assess the extent to which the native bush might impact on the production potential of the farm, farmers were asked about the physical characteristics of their bush (such as topography and production potential). Figure 4 shows that $60 \%$ of bush remnants are less than 2 ha and another $16 \%$ are from 2 to 4 ha, meaning that more than three-quarters are less than 4 ha in area. Only $13 \%$ were more than 8 ha in area. In other words, most of the bush remnants were small and did not take up much of the area of the farm.

Farmers were asked to describe the prevailing topography of their bush. Two thirds indicated that their bush was on land that is 'difficult' or sensitive to damage. Thirty-eight percent of remnants were on steep land, 33\% were on

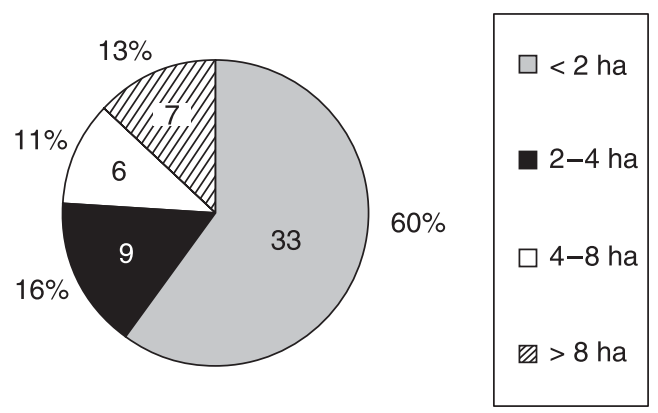

Figure 4 Number and percentage of farmers reporting forest remnants by size of the remnant.

land that was mostly flat to gently rolling, and $29 \%$ were on 'other'.

Figure 5 shows the proportion of remnants in different size categories by prevailing topography. The first column shows that $44 \%$ of remnants under 2 ha are on land that is mostly flat or gently rolling. The second column shows that most of the 2-4 ha remnants are on land that is mostly steep; the third column shows that remnants of $4-8$ ha are evenly distributed on different types of topography; and the last column shows that all of the remnants over 8 ha are on land that is mostly steep or 'other' (i.e. 'difficult' in some way). The figure suggests that fragments on flat or gently rolling land are most likely to be small, while larger remnants tend to be on rougher ground. However, it is worth noting that four of the 15 (a quarter) of the fragments between 2 and 8 ha are on easy land.

In summary, we can infer that steep topography has an influence on the survival of native

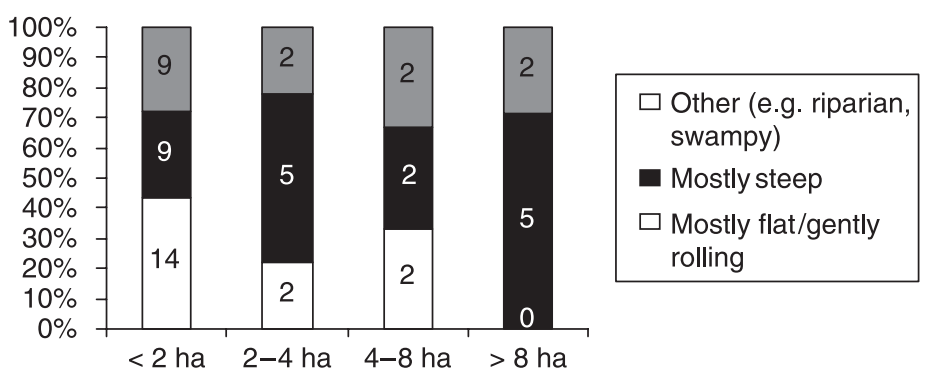

Figure 5 Proportion of forest fragments by size category and prevailing topography. 


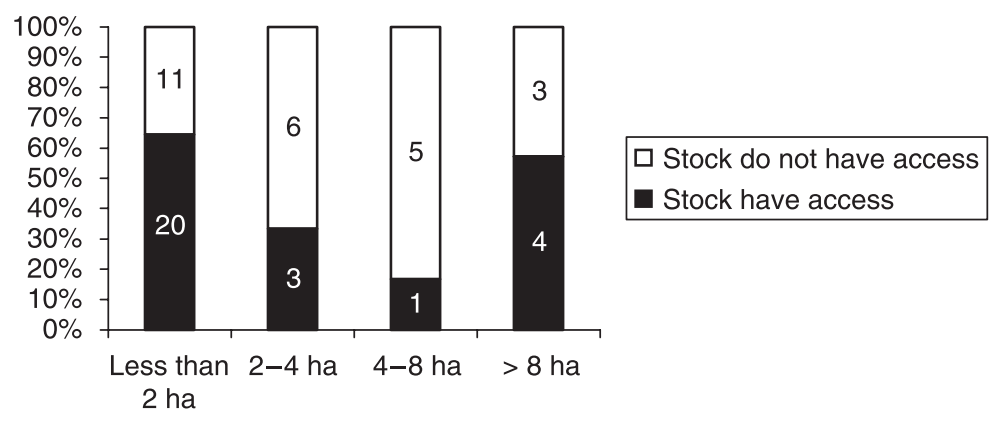

Figure 6 Stock access to forest remnants by area size of remnant.

forest, but more so in relation to large than small bush remnants.

Farmers were asked if the bush was on land that could be cleared for production, in whole or in part. Fifty-four percent (30 out of 56) reported that the land had potential for dairy production. In other words, a majority of farmers had retained native forest on land that had potential to be used for dairy production, although, as indicated earlier, two-thirds of the fragments were on land that is in some way difficult to farm.

Figure 6 shows that the larger fragments, especially those of $2-4$ ha and $4-8$ ha are more likely than not to be protected from stock. In practical terms, we can infer that the small stands of kahikatea forest scattered through the Waikato landscape are less likely to experience protection from stock than stands of mixed bush, fern and scrub on gullies and steep slopes. Figure 7 shows a typical example of a small native forest remnant that reflects the effect of stock access. There is a gap between the ground level, where hardy exotic weeds flourish, and the canopy. The gap results because canopy species are unable to survive stock browsing and trampling.

Farmers were asked their reasons for allowing stock access. These included: 'haven't got around to fencing it'; 'used for stock shelter'; 'there's no practicable access'; 'can't afford to retire the land completely'; 'I want to keep the area tidy so let the stock just to trim the grass.' These answers suggest that many farmers do not know about the damaging effect of stock
Table 1 Percentage of farmers answering 'yes', 'no' or 'don't know' to possible values of their bush remnants

\begin{tabular}{lrllll}
\hline & & & \multicolumn{2}{c}{ Don't } & Total \\
Uses of bush remnant & Yes & No & know & number \\
\hline Provides stock shade/shelter & 77 & 23 & - & 56 \\
Provides a windbreak & 55 & 45 & - & 56 \\
Provides timber & 7 & 92 & - & 55 \\
Improves property values & 41 & 36 & 23 & 56 \\
Protects soil or water & 41 & 58 & - & 55 \\
Provides wildlife habitat & 36 & 64 & - & 55 \\
Provides recreation & 26 & 74 & - & 54 \\
\hline
\end{tabular}

on bush, do not value their bush sufficiently to afford it protection, or cannot afford fences to keep stock out.

Farmers were asked about their use of the bush in an effort to discover how they valued it. Table 1 shows that a majority of farmers with bush $(77 \%)$ indicated that it provides stock with shade and shelter. Over half $(55 \%)$ indicated that their bush provided a windbreak. Only a minority (41\%) perceived bush as valuable to provide soil and water protection. Twenty-six percent obtained recreational value from their bush. Less than half (41\%) thought that bush could improve the value of the property.

In terms of age of the farm, Burns et al. (2000) have suggested that remnants are gradually lost over time as a result of inappropriate management, neglect, changes of farm ownership, or other reasons. Farms with bush and those without were compared in terms of how 


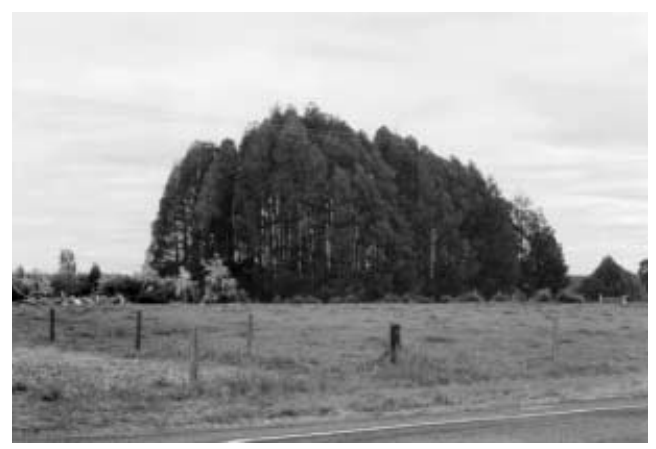

Figure 7 'See-through' bush, a typical example of a small, unprotected kahikatea remnant showing no understorey regeneration.

long they had been a dairy farm. Although numerically more bush remnants were reported for the oldest category of farms, Figure 8 shows that proportionately, the youngest and the oldest farms are less likely to have bush than the farms in the middle category. The middle column shows the proportion of farms with bush is greater than younger or older farms in the columns to either side.

This finding supports the view that there is a progressive loss of forest remnants over time and that more recently converted farms are less likely to support bush, possibly because the high cost of land in the Waikato makes buyers less likely to buy a farm that includes native bush.

In terms of farm size, Figure 9 shows that the smallest farms were less likely to support bush remnants, while the largest farms were more likely. However, the figures also suggest something more complex than a straightforward relationship between size and presence or absence of bush. In a straight area-to-bush relationship, one would expect a gradation from small farms with little bush to large farms with a good deal of bush. In this sample, farmers with medium and medium-small farms are

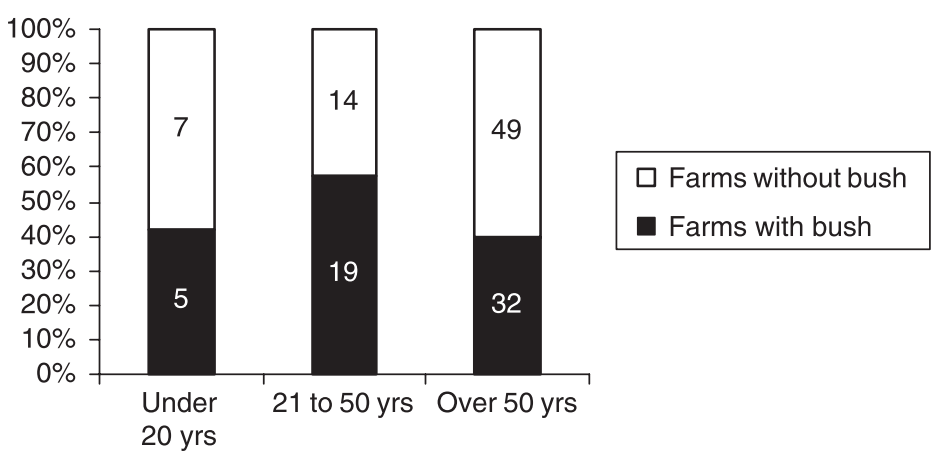

Figure 8 Percentage of farmers reporting they have bush or no bush by age category of farm.

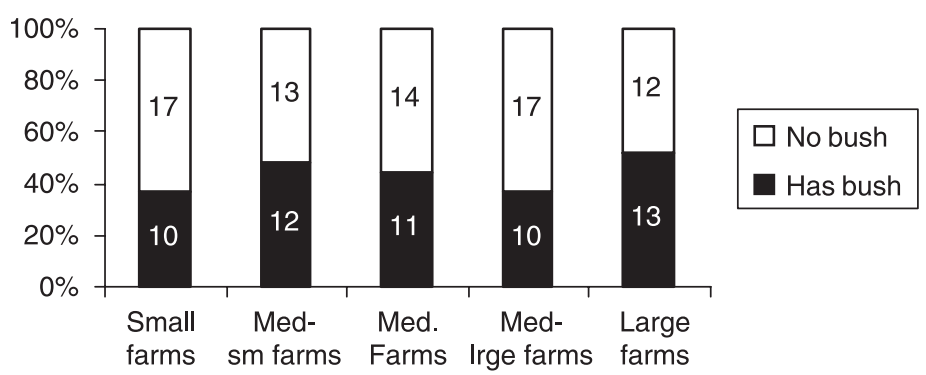

Figure 9 The proportion of farms in different size categories with and without native forest remnants. 


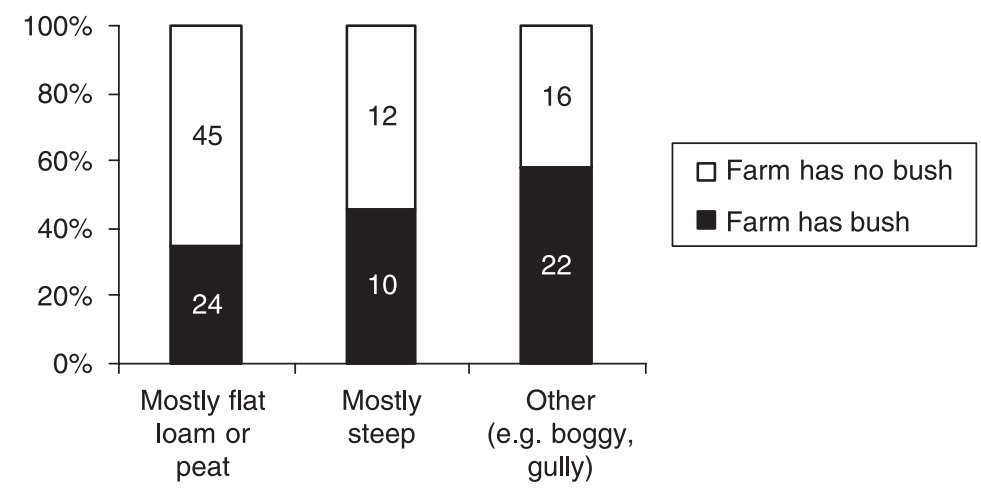

Figure $\mathbf{1 0}$ Forest remnants by predominant type of topography on the farms.

more likely to have bush than the mediumlarge farms. A point to note by those who argue that small farm owners cannot afford the 'luxury' of retaining bush, is that 22 farmers in the two smallest farm-size categories reported bush, compared with 23 in the two largest farm-size categories (i.e. $42 \%$ of the smallest farms had bush compared with $44 \%$ of the largest farms).

Turning to topography, there is a clear and positive relationship between steep or otherwise difficult topography and presence or absence of native forest. As one would expect from a practical viewpoint, farms with steep topography are significantly more likely to have bush than those with mostly flat topography. Figure 10 shows the relative proportion of farms with and without bush by type of topography.

Less than $40 \%$ of farms on flat land had bush, compared with nearly $60 \%$ of farms with 'other' (mostly difficult) topography. It thus seems clear that overall topography of the farm may be a significant factor that encourages the retention of native bush by dairy farmers. However, while it would be easy to assume that forest remnants have been left simply because the land is too steep to farm, it is worth noting that 24 of the 56 farms with bush (i.e. $43 \%$ ) are on land that is mostly flat. In short, steep or broken topography may be a strong reason for retaining bush, but it is not the only reason, or even a determining reason. Some farmers have clearly allowed bush to remain on land that could have been easily managed for dairy production.

\section{Farmers with and without bush on their farm: is there a difference?}

Nearly a fifth of all farmers (19\%) who replied to the survey reported that they had native bush that was protected from stock access. Protection from stock requires fencing (a relatively costly exercise) and implies active management and commitment by the farmer. It is likely that these 'farmers with bush' are ones who approximate the 'conservation' farmers interviewed in the qualitative stage of the research.

By contrast, farmers with bush that was open to stock varied considerably in their attitudes and their knowledge of appropriate management. While $48 \%$ of all the farmers with bush said that they would 'mind a lot' if the bush were cut down, 34\% said they would mind 'somewhat' and $18 \%$ said that they would not mind if the bush were cleared. When asked reasons for allowing stock access, answers included, 'haven't got round to fencing it', 'it provides stock shelter', 'its used for production', 'can't afford to retire the land completely' and 'want to keep the area tidy/to trim the grass'.

In short, the 'farmers with bush' spanned a spectrum of attitudes and perceptions in relation to their bush, from highly committed at one end, to neglectful or uncaring at the other. Many of the uncommitted farmers were mildly positive, but did not appreciate the bush sufficiently or did not have the knowledge to afford appropriate protection. 
Judging by the qualitative survey and comments from the questionnaire survey, conservation farmers (including farmers with bush protected from stock access) tend to pay more attention to the farm, and 'farm to what's around them'. Detailed knowledge of a farm, built up over seasons, can be assumed to be all-important if farming practice is to accord with the long-term physical capacity of the land. The importance of this close knowledge emerged clearly when one conservation farmer described the way he assessed parts of his land for tree planting:

We just got that way where we think instinctively of pro-retirement with any piece of land that's showing sign of being damaged, whether that's because it faces the south or is shaded. On this farm, there's quite a lot of southerly facing slopes and they don't grow pasture well. In the winter they just grow predominantly moss. And that doesn't hold the turf together, well there isn't any turf, so as soon as cattle walk on it, they tread it badly. And when that happens in the winter, the following spring the effect of the stock trampling on it is just like cultivation. And that allows weeds to get established and you've got to, you've got to be more expensive with inputs for keeping the weeds at bay while you struggle to promote the pasture on a southerly facing slope that will never grow pasture full stop. So what are you doing persisting? Do you really do yourself a favour ...!

But the difference between farmers is not so much linked to the presence or absence of remnant forest on their property (which is mostly an accident of history) as it is linked to different philosophies of farming and relationships to the land. Some farmers tend to "farm to the land' - paying attention to the capabilities of the land, managing stock within the constraints of contour, soil, drainage and aspect, and seeking the balance between production and environmental amenity. Other farmers tend to 'farm to the book' and regard the land as a factor of production. The former have developed ties of attachment to the farm as a place to live as well as a business and a source of income. The latter are more inclined to see the farm primarily as a business.

Lack of experience and long-term knowledge about the particular area may be one factor that encourages farming by formula rather than farming to the land and its environmental conditions. Results from the questionnaire survey indicated that $56 \%$ (72 of 129) of dairy farmers in the Waikato had been on their farm for less than 10 years, and 33\% (42 of 129) had been on their farm less than five years. The qualitative component of the research provided the distinct impression that younger farmers tended to farm 'by the book' (including the bank account book) compared with older farmers who tended to be guided by their experience.

Profit and production are important to both types of farmer, but those who farm to the land are more likely to be guided by local and personalized standards of production according to the conditions of the farm. They are also more likely to retain and protect bush on their land. It is significant that owner/managers are more likely to have remnant forest on their farm than either sharemilkers or owners who are not managing the farm (Fig. 3). It is also significant that farmers in the 45-55-year-old age range are more likely to have bush on their property than younger farmers (Fig. 2). Owner/ occupiers, and farmers in the 45-55-year-old age range have more incentive and a greater capacity to assign a higher priority to the amenity values of their farm than younger farmers, sharemilkers or absentee owners.

In the early stages of the research, I assumed the presence or absence of remnant forest would indicate position on a continuum between production-focused farmers at one end and environmentally aware farmers at the other, and that farmers at both ends would be different in their values, attitudes and farming philosophy. Instead, evidence from the study suggests that similarities of attitude and value are greater among Waikato dairy farmers than the differences. Differences do exist, but simple presence or absence of native forest is not an indicator of farming priorities because in many 
cases the presence of bush on a farm is an accident of history. There are 'conservationist' farmers who do not have native forest, and there are forest remnants that persist in spite of the priorities of the landowner.

\section{Conclusion}

The last point leads back to the introduction and the two research questions, why is there so little native vegetation left in the Waikato? And, why is there any native bush left in the Waikato? What do the research findings suggest about the human dimensions of biodiversity conservation on private land?

A first conclusion is that the economic drivers of an industrial agriculture encourage the majority (perhaps as many as $80 \%$ ) of dairy farmers to prioritize production to the neglect of environmental care and conservation of native biodiversity. Biophysical aspects such as topography, aspect, soil type and hydrology, can make it difficult or easy for farmers to remove native vegetation and thereby speed up or slow down the process of biodiversity loss. But the evidence of Figure 8 which showed that older farms are proportionately least likely to support bush suggest that economic factors over time have led to erosion of native biodiversity, regardless of other factors.

Notwithstanding the economic pressures towards production, small native forest remnants are widespread throughout the Waikato and Hauraki Plains, with $43 \%$ of dairy farms reporting some element of native vegetation. Looking first at the factors that assist the survival of native forest regardless of the attitudes of the farmer, topography of the remnant and of the farm appear to be the factors which influence bush survival most significantly although they by no means determine bush survival. Forest remnants were more frequent and likely to be larger on 'difficult' farms than 'easy' farms. Although 35\% of the farms with bush were on easy rolling or flat topography, their areas of bush were likely to be small and unprotected from livestock. At the risk of overgeneralizing, the most common bush remnants in the dairy lands of Waikato and Hauraki
Plains are small areas of unprotected kahikatea or wetland forest on farms that are predominantly flat or gently undulating, and larger areas on farms that are difficult in some way (e.g. include gullies, steep slopes or swampy areas difficult to drain).

Considering the farmers from the perspective of biodiversity conservation, it is possible to distinguish at least three groups: committed conservationists, pragmatists and uncommitted conservationists, and opposers. Committed conservationists include those who have covenanted land and 'farmers with bush' who have protected their bush from stock. They maintain areas of native bush for a variety of reasons, including aesthetic enjoyment and pragmatic reasons such as 'better to make an asset out of it than fight it'. Conservationists are most likely to be in the 45-54-years-old age group, with less economic pressure in terms of debt servicing, and perhaps less need to prove themselves as a 'gun' farmer. They are likely to include those who have the greatest emotional commitment to their farm as a place to live and, because of their familiarity with the land are most likely to 'farm to the land'.

Pragmatists and uncommitted conservationists include those who like native bush but are not prepared to divert energy or resources from production to conservation. They could be persuaded to fence off their bush by pragmatic arguments or economic incentives but are otherwise inclined to let the bush slowly die. They are more likely to 'farm to the book', including the financial calculations that tell them converting a patch of swampy forest or steep hillside will not yield a profitable return. They could be younger farmers who feel some interest and commitment to native forest as an element of New Zealand identity, but have become farmers during the last 15 years when farmers have received no assistance from the state, and have experienced the message over and over again of the need for efficiency and profitability.

Opposers include those who are actively opposed to native bush because they consider it to be untidy, a sign of laziness, a source of pests and weeds or a waste of productive land. 
Opposers may be older farmers or younger farmers who want to maximize their production returns to pay off a mortgage or prove their ability as a farmer. Policies for encouraging the protection of biodiversity on private land are likely to be most effective where they can assist the financial capacity of would-be committed conservationists (e.g. by subsidizing the cost of fencing) and by offering the pragmatists a practical and utilitarian reason for retiring and fencing off land with native vegetation from production.

\section{Endnotes}

1 Except in the case of a few regional councils that provide assistance in the form of grants to cover part of the cost of fencing, and stock troughs to compensate for the loss of stock access to waterways.

2 A significant portion of former wetland still remains under the administration of the Department of Conservation as Whangamarino Wetland, and Kopuatai Peat Dome.

3 All farmers involved in the research were able to be compared in terms of herd size, farm size and milk production against the average for farmers in their region as published by the Livestock Improvement Corporation Dairy Statisics (Livestock Improvement Corporation 2000).

4 Because farmers were the source of information, the answers reflect farmers' definitions of native bush rather than those of a botanist. Hence the bush areas may include vegetation that is partly exotic in composition. From the viewpoint of biodiversity, however, a mixture of natives and exotics is more varied than an all-production landscape of pasture and commercial pines.

5 Many native plants are palatable to stock and vulnerable to damage. In addition, stock cause damage to roots and compaction of forest litter and soil. Almost any access by stock is enough to eliminate native groundcovers (e.g. sedges, grasses, mosses, lichens and ferns) and regeneration of larger trees and shrubs.

6 'Other' included swampy and riparian areas, or areas made up of a complex mix of topography. For the most part 'other' included land that was 'difficult' in some way.

\section{References}

Atkinson IAE, Cameron EK (1993). Human influence on the terrestrial biota and biotic communities of New Zealand. Trends in Ecology and Evolution 8, 447-51.

Benton TG, Vickery JA, Wilson JD (2003). Farmland biodiversity: is habitat heterogeneity the key? Trends in Ecology and Evolution 18 (4), $182-8$.

Bonanno A, Busch L, Friedland WH, Gouveia L, Mingione E, eds (1994). From Columbus to Congagra: the Globalization of Agriculture and Food, University Press of Kansas, Lawrence.

Boothroyd IKJ, Crush JR, Ledgards SF, Huser B, Selvarajah N (2000). Impact of nitrogen flows from agricultural production environments on non-agricultural ecosystems in the Waikato region, New Zealand. In: Craig JL, Mitchell N, Saunders DA, eds. Conservation in Production Environments, Managing the Matrix. Nature Conservation 5. Surrey Beatty and Sons, Chipping Norton, pp. 236-45.

Bowler IR (1992). The industrialisation of agriculture. In: Bowler IR, ed. The Geography of Agriculture in Developed Market Economies, Longman Scientific and Technical, Harlow, Essex, pp. 7-31

Bradshaw B, Cocklin. C, Smit B (1998). Subsidy removal and farm-level stewardship in Northland. New Zealand Geographer 54 (2), 12-20.

Burch D, Goss J (1999). Global sourcing and retail chains: shifting relationships of production in Australian agri-foods. Rural Sociology 64 (2), 334-50.

Burns B, Barker GM, Harris R, Innes J (2000). Conifers and cows: forest survival in a New Zealand dairy landscape. In: Craig JL, Mitchell N, Saunders DA, eds. Conservation in Production Environments, Managing the Matrix. Nature Conservation 5. Surrey Beatty and Sons, Chipping Norton, pp. 26-34.

Champion P (1988). The Ecology and Management of Kahikatea Dacrycarpus dacrydioides (A.Rich.) de Laubenfels in the Waikato, North Island. Master of Science Thesis, University of Waikato, Hamilton, New Zealand.

Cocklin C, Dorman P (1994). Ecosystem protection and management in New Zealand: a private land perspective. Applied Geography 14, 264-81.

Council of Europe (2002). The impact of agricultural policies on biological diversity and landscape. STRA-CO/AGRI (2001) 13. Compiled for the Pan-European Conference on Agriculture and Biodiversity, organised by Republic of France, Council of Europe and United Nations Environment Programme, June 5-7, 2002.

Davis P, Cocklin C (2000). Who pays? Habitat protection on private land. In: Craig JL, Mitchell N, Saunders DA, eds. Conservation in Production 
Environments, Managing the Matrix. Nature Conservation 5. Surrey Beatty and Sons, Chipping Norton, pp. 168-79.

Department of Conservation and Ministry for the Environment (2000). Our Chance to Turn the Tide, Department of Conservation and Ministry for the Environment (New Zealand), Wellington.

Ehrlich P, Ehrlich A (1981). Extinction: The Causes and Consequences of the Disappearance of Species, Random House, New York.

Environment Waikato (1998). Waikato State of the Environment Report, Environment Waikato (Waikato Regional Council), Hamilton, New Zealand.

Fairweather J, Keating NC (1994). Goals and management styles of New Zealand farmers. Agricultural Systems 44 (2), 181-200.

Fonterra Co-operative [homepage on the Internet] (2004). Media backgrounder. Fonterra Cooperative, New Zealand. Available at: http:// www.fonterra.com/content/news/mediabackground/default.jsp (Cited 14 March 2004).

Friedland WH, Busch L, Buttel FH, Rudy A, eds (1991). Towards a New Political Economy of Agriculture, Westview, Boulder.

Holland PG (1997). Living on an island: the need for environmental management. Proceedings of the $2^{\text {nd }}$ Joint Conference of the Australian Institute of Geographers and the New Zealand Geographical Society, Hobart, Australia, pp. 611.

Jones D, Cocklin C, Cutting M (1995). Institutional and landowner perspectives on wetland management in New Zealand. Journal of Environmental Management 45, 143-61.

Lambeck J Jr, Cale P, Ive J, Leone J (2000). Nature conservation in agricultural landscapes: an integrated planning approach. In: Craig JL, Mitchell N, Saunders DA, eds. Conservation in Production Environments, Managing the Matrix. Nature Conservation 5. Surrey Beatty and Sons, Chipping Norton, pp. 166-78.

Leathwick JR, Clarkson BD, Whaley PT (1995). Vegetation of the Waikato Region: Current and Historical Perspectives. Landcare Research Contract: Report: LC9596/022, Prepared for Environment Waikato, Landcare Research, Hamilton.

Livestock Improvement Corporation (2000). Dairy Statistics 1999-2000. Livestock Improvement Corporation, Hamilton.

Livestock Improvement Corporation (2003). Dairy Statistics 2001-2002. Livestock Improvement Corporation, Hamilton.

Ministry of Agriculture and Forestry [website] (2004a). Statistics $>$ primary industries $>$ regions $>$ tables: Waikato Region, Total Sheep, Beef and Dairy Cattle at 30th June. Ministry of Agriculture and Forestry, Wellington. Available at: http:// www.maf.govt.nz/statistics/primaryindustries/ regions/tables/waik.htm (cited 15 April 2005).

Ministry of Agriculture and Forestry [website] (2004b). Statistics $>$ primary industries $>$ livestock $>$ dairy: Total Dairy Cattle as at 30th June. Ministry of Agriculture and Forestry, Wellington. Available at: http:/www.maf.govt.nz/statistics/primaryindustries/ livestock/dairy/dairy.htm (cited 15 April 2005).

McMichael P, ed. (1994). The Global Restructuring of Agro-Food Systems. Cornell University Press, Ithaca, NY.

Menzies D (1999). Clean and Green? Environmental Quality on the New Zealand Dairy Farm. PhD Thesis. Lincoln University, Lincoln, New Zealand.

Ministry for the Environment (1997). The State of Our Biodiversity. In: The State of New Zealand's Environment 1997. GP Publications, Wellington, 9.1-9.176.

Ministry for the Environment (2000a). Bio-What? Preliminary Report of the Ministerial Advisory Committee to the Minister for the Environment, addressing the effects of Private Land Management on Indigenous Biodiversity. Ministry for the Environment (New Zealand), Wellington.

Ministry for the Environment (2000b). Biodiversity and Private Land. Final Report of the Ministerial Advisory Committee to the Minister for the Environment, addressing the effects of Private Land Management on Indigenous Biodiversity. Ministry for the Environment (New Zealand), Wellington.

Mitchell N, Craig JL (2000). Managing the matrix: realigning paradigms toward sustainability. In: Craig JL, Mitchell N, Saunders DA, eds. Conservation in Production Environments, Managing the Matrix. Nature Conservation 5. Surrey Beatty and Sons, Chipping Norton, pp. 26-34.

Mooney HA, Lubchenko J, Dirzo R, Sala OE (1995). Biodiversity and ecosystem functioning: basic principles. In: Heywood VH, Watson RT, eds. Global Biodiversity Assessment. Cambridge University Press, Cambridge, pp. 275-326.

Norton DA, Miller CJ (2000). Some issues and options for the conservation of native biodiversity in rural New Zealand. Ecological Management and Restoration 1 (1), 26-34.

Parminter T, Perkins AML (1997). Applying an understanding of farmers' values and goals to their farming styles. New Zealand Grassland Association 59, 107-11.

Parliamentary Commissioner for the Environment (2001). Weaving Resilience into our Working Lands: future roles for native plants on private land. Parliamentary Commissioner for the Environment, Wellington. 
Potter C (1998). Against the Grain, Agri-Environmental Reform in the United States and the European Union, CAB International, Wallingford, Oxford.

Pritchard WN (1998). The emerging contours of the third food regime: evidence from Australian dairy and wheat sectors. Economic Geography. $\mathbf{7 4}$ (1), 64-74.

Pryde PR, Cocklin C (1998). Habitat islands and the preservation of New Zealand's avifauna. Geographical Review 88 (1), 86-113.

QEII (2002). Report of the Queen Elizabeth the Second National Trust for the year ended 30 June 2002. Queen Elizabeth the Second National Trust, Wellington.

Rauniyar GP, Parker WJ (1998). Constraints to Farm Level Adoption of New Sustainable Technologies and Management Practices in New Zealand Pastoral Agriculture. MAF Technical Policy Paper. Ministry of Agriculture and Forestry (New Zealand), Palmerston North.

Rhodes T, Willis B, Smith W (2000). Impediments to Optimising the Economic and Environmental Performance of Agriculture Vol. 1: A Study of Issues Affecting North Island Hill Country Farmers. Technical Paper 2000/17, MAF Policy, Ministry of Agriculture and Forestry (New Zealand), Wellington.

UK Government (1994). Biodiversity, the UK Action Plan. Her Majesty's Stationary Office, London. Underwood R, Ripley J (2000). Impediments to Optimising the Economic and Environmental Performance of Agriculture. Vol. 2: Review of Literature. MAF Policy, Ministry of Agriculture and Forestry (New Zealand), Wellington.

Vandermeer J, van Noordwijk M, Anderson J, Ong C, Perfecto I (1998). Global change and multi-species agroecosystems: Concepts and Issue. Agriculture, Ecosystems and Environment 67, 1-22.

Western D (1989). Conservation without parks: wildlife in the rural landscape. In: Western D, Pearl M, eds. Conservation for the Twenty-First Century. Oxford University Press, New York.

Wilson GA (1992). A Survey on Attitudes of Landholders to Native Forest on Farmland. Journal of Environmental Management 34, 117-36.

Wilson GA (2001). From productivism to postproductivism and back again? Exploring the (un) changed natural and mental landscapes of European agriculture. Transactions of the Institute of British Geographyraphers, NS 26, 77-102. 